\title{
POR MAIS E MAIOR VISIBILIDADE DA PESQUISA DESENVOLVIDA POR LINGUISTAS BRASILEIROS
}

\section{FOR GREATER VISIBILITY OF THE RESEARCH CARRIED BY BRAZILIAN LINGUISTS}

\author{
Mailce Borges Mota \\ Universidade Federal de Santa Catarina / CNPq \\ Florianópolis, Santa Catarina, Brasil
}

Em um contundente artigo publicado na Revista da ANPOLL 29, número comemorativo dos 25 anos de existência da Associação, Baronas (2005) defende a ideia de que as associações brasileiras de estudos linguísticos, a ANPOLL incluída, têm a importante responsabilidade política de implementar medidas para a "divulgação científica qualificada dos saberes produzidos pelos linguistas brasileiros" (p. 251), destacando que a Linguística é uma das ciências mais produtivas no Brasil. No sentido de colaborar com a disseminação da pesquisa desenvolvida na área de Linguística e Literatura e promover maior visibilidade desse conhecimento, a Revista da ANPOLL reorganizou seu fluxo editorial a fim de aprimorá-lo para adequar a Revista às normas de bases de indexação e, em consequência, melhorar o alcance dos artigos que publica. A partir de 2018, a Revista passa a ser quadrimestral e apresentará um número dedicado aos estudos linguísticos, um número voltado aos estudos literários e um número temático abordando a pesquisa conduzida no âmbito dos Grupos de Trabalho da ANPOLL.

Como pode ser visto a seguir, o número 45 da Revista está volumoso porque rico na diversidade de temas abordados pelos trabalhos selecionados para esta edição. A seção de Artigos do número 45 é aberta com o trabalho " $A$ nasalidade vocálica em espanhol: um estudo de percepção", de Luciene Bassols Brisolara e Carmen Lúcia Barreto Matzenauer. No estudo, as autoras investigam a percepção da vogal /a/ do espanhol em contextos nasais por falantes nativos do espanhol uruguaios e concluem que a nasalidade fônica é, até certo ponto, percebida por estes falantes, principalmente em testes de discriminação. Em "Restrições linguísticas na palatalização do /s/ pós-vocálico seguido de [t] ou [t] na fala de Caravelas-Bahia", Jares Gomes Lima e Maria Marta Pereira Scherre analisam, a partir da Teoria da Variação e Mudança Linguística, a influência dos fatores de restrições linguísticas na variação de fricativas coronais na fala da comunidade de Caravelas, município no sul da Bahia. Os autores demonstram que o processo de palatalização na comunidade é altamente estruturado e só ocorre diante de [t] e [t] . Em seguida, Ana Paula da Silva Passos Jakubów e Letícia Maria Sicuro Corrêa relatam os resultados de um experimento psicolinguístico no artigo "A expressão morfofonológica da concordância de número variável em português brasileiro: uma proposta para a aquisição e a produção infantil". Conduzido com crianças em idade pré-escolar de escolas públicas e particulares, o estudo mostra que as crianças de escola pública não apresentam preferência 
quanto à concordância de número interna ao DP sujeito. Já as crianças de escolas privadas preferem as formas redundantes. As autoras propõem que a representação gramatical morfofonológica de número plural é afetada pela frequência e informações de uso na codificação durante a produção da linguagem.

No artigo "Objeto nulo e pronome pleno na retomada anafórica em PB: uma análise em corpora escritos com características de fala", Gabriel de Ávila Othero, Sonia Cyrino, Giulia Schabbach, Leonardo Madrid Alves e Rodrigo Rosito têm dois objetivos principais: comparar duas hipóteses sobre a retomada anafórica de objeto direto em PB e verificar a distribuição das estratégias de retomada anafórica em dois corpora, sendo um constituído de histórias em quadrinhos infantis e o outro, de postagens do Twitter. A análise dos dados leva os autores a concluírem que referentes animados tendem a favorecer a retomada pronominal, enquanto referentes não animados favorecem a retomada com o objeto nulo. Os autores apresentam, ainda, 5 generalizações empíricas sobre as estratégias de retomada anafórica de objeto direto no PB.

A partir da Teoria Exo-esqueletal, Rafaela do Nascimento Melo Aquino, Isabella Lopes Pederneira e Miriam Lemle exploram, com dados do PB e do espanhol, as maneiras pelas quais palavras com múltiplas camadas morfológicas ganham novos significados. No artigo "A relação raiz e estrutura sintática na semântica da formação de palavras no português brasileiro e espanhol", uma das conclusões das autoras é a de que cada língua se servirá, em diferentes escalas, dos mecanismos que permitem o surgimento de novos significados em palavras complexas. Em "Padrões de marcação possessiva em línguas ameríndias: um enfoque tipológico", Paulo Henrique Pereira Silva de Felipe mostra como um grupo de 39 línguas indígenas, que são faladas ou já foram faladas na América do Sul, se comporta em relação aos padrões de marcação possessiva. O objetivo geral do estudo foi verificar se as línguas analisadas determinavam preferência por algum tipo de padrão possessivo. Já a partir da perspectiva sociopragmática, Marinalda Freitas Valentim, Marina Fagundes de Oliveira Lacerda e Zenaide de Oliveira Novais Carneiro voltam-se para o estudo da relação entre formas de tratamento e papéis sociais. Em seu artigo, intitulado "Formas de tratamento no limiar do século XX: uma análise sociopragmática", as autoras analisam as formas tratamentais na posição de sujeito pleno nas Cartas para Severino Vieira, Governador da Bahia. No artigo "A Teoria Sentido-Texto e suas possibilidades de aplicação em dicionários de aprendizes do espanhol", Laura Campos de Borba volta-se para o estudo de colocações nesse tipo de dicionário concluindo que a Teoria Sentido-Texto oferece uma abordagem eficaz para a descrição de colocações.

Em "A prova de redação como um desafio ético: o caso do vestibular da UERJ", Gustavo Bernardo, Isabel Cristina Rodrigues e Bruno Deusdará apresentam uma reflexão crítica sobre o que denominam deslocamentos nas práticas de linguagem que fazem parte do processo de produção e avaliação de redações no exame de ingresso ao Ensino Superior na UERJ. No artigo seguinte, que tem como título "O desafio da profissão de professor no Brasil: uma análise avaliativa da linguagem em um artigo de opinião", Ana Paula Carvalho Schmidt, Anidene de Siqueira Cecchin, Nédilã Espindola Chagas e Sara Regina Scotta 
Cabral apoiam-se no arcabouço do sistema de avaliatividade para examinar os elementos léxico-gramaticais de um artigo de opinião sobre os desafios da profissão docente no Brasil. Em suas considerações finais as autoras ressaltam que o uso de subsistemas de avaliatividade, principalmente os de atitude (de julgamento e apreciação) e de gradação, contribui para a construção da visão do autor sobre o preparo profissional do professor e suas consequências para o ensino no Brasil. Também na perspectiva da Análise do Discurso, Mara Lucia Martins Rodrigues e Ana Luiza Artiaga Rodrigues da Motta examinam, no artigo "Família na contemporaneidade brasileira: sentidos em curso", como a palavra família tem seus sentidos constituídos no discurso jurídico e em textos veiculados na mídia quando da discussão sobre o Estatuto da Família. Em "A noção de corpo em Saussure e em Freud: um encontro paradoxal", Glória Maria Monteiro Carvalho e Maria de Fátima Vilar Melo problematizam e discutem o lugar tomado pelo corpo do falante nas teorias dos dois autores. Wilder Kleber Fernandes de Santana e Pedro Farias Francelino, fundamentando sua análise na concepção de linguagem do Círculo de Bakhtin, abordam "A representação linguístico-discursiva de Jesus Cristo em seu sermão sobre o cumprimento do amor a partir do Evangelho segundo São Mateus". No artigo seguinte, Clemilton Lopes Pinheiro e Juzelly Fernandes Barreto Moreira, apresentam uma proposta teórica para a discussão epistemológica sobre o conceito de estilo. Raul de Carvalho Rocha e Núbia Rabelo Bakker Faria, em "Da exaltação da língua alemã à Linguística do século XIX", revisitam as obras e ideias de Jacob Grimm, com o objetivo de demonstrar a influência dos ideais românticos na consolidação da Linguística como disciplina. Roberto Leiser Baronas e Júlio Bonatti fecham a seção de artigos discutindo a construção de dupla imagem do autor Noam Chomsky (Chomsky duplo e Chomsky único), com base nos pressupostos da análise do discurso segundo Maingueneau. Este número da Revista da ANPOLL traz ainda uma entrevista com o neurocientista Peter Hagoort, Diretor do Max Planck Institute for Psycholinguistics e do Donders Center for Cognitive Neuroimaging, sobre a relação entre linguagem, cognição e cérebro.

Esperamos que os trabalhos aqui apresentados inspirem outros e desejamos a todos boa leitura.

\author{
Mailce Borges Mota \\ Universidade Federal de Santa Catarina \\ Florianópolis, Santa Catarina, Brasil \\ Mailce.Mota@ufsc.br
}

\title{
REFERÊNCIA
}

Baronas, R.L. Da necessidade premente de se cometer uma política de divulgação científica qualificada dos trabalhos da linguística do Brasil. Revista da ANPOLL, 29, 235-258, 2005. 